\title{
Pola Jaringan Komunikasi Layanan Kesehatan bagi Penyandang Disabilitas Korban Erupsi Gunungapi Merapi
}

\author{
Wuri Rahmawati ${ }^{1}$ dan Hari Akbar Sugiantoro ${ }^{2 *}$ \\ Universitas 'Aisyiyah Yogyakarta \\ Email : wurirahma_w@unisayogya.ac.id’ dan hariakbarsugiantoro@unisayogya.ac.id²* \\ *corresponding author
}

\begin{abstract}
Keywords:
Pattern of Communication

Network,Disability,Disaster,

Eruption, Health Service.
\end{abstract}

\begin{abstract}
The objective of this research is to know the health service communication network design especially for disability communities. This research used a qualitative method with purposive sampling. Informant of this research are disabilities,government, NGO and volunteer. Primary and secondary data used in this research. Interview, forum group discussion and observation are to get primary data and than writing and documentation are to get secondary data The results of this research showed that the disability communities as victims of the Merapi volcanic eruption in 2010 had not received special treatment either during evacuation or while in refugee camps. Pattern of communication network for health services for victims of Merapi volcanic eruptions, namely the wheel pattern. Volunteers as sources or information center regarding the availability of health services for disaster victims. The health services communication network design for disabilities communities is volunteers as Liaison (person who outside the group that connect disabilities groups with medical team groups), medical teams as opinion leaders (people who are asked for opinions on health and influence disabilities to behave accordingly with recommendations in the treatment and prevention of diseases and persons with disabilities (deaf) as isolates (person that have very limited or minimal to access health services information as a result of their limitations and methods of delivering information using loudspeakers.
\end{abstract}

\begin{abstract}
ABSTRAK
Tujuan dari penelitian ini adalah untuk mengetahui desain jaringan komunikasi layanan kesehatan terutama untuk masyarakat penyandang disabilitas. Penelitian ini menggunakan metode kualitatif dengan purposive sampling. Informan penelitian ini adalah disabilitas, pemerintah, LSM, dan sukarelawan. Data primer dan sekunder yang digunakan dalam penelitian ini adalah wawancara, diskusi kelompok forum dan observasi. Hasil penelitian ini menunjukkan bahwa masyarakat penyandang disabilitas sebagai korban letusan gunung berapi Merapi pada tahun 2010 belum menerima perlakuan khusus yang baik selama evakuasi atau saat berada di kamp-kamp pengungsi. Pola jaringan komunikasi untuk layanan kesehatan bagi korban letusan gunung berapi Merapi, yaitu pola roda. Relawan sebagai sumber atau pusat informasi mengenai ketersediaan layanan kesehatan bagi korban bencana. Desain jaringan komunikasi layanan kesehatan untuk komunitas disabilitas adalah sukarelawan sebagai penghubung (orang yang berada di luar kelompok yang menghubungkan kelompok disabilitas dengan kelompok tim medis), tim medis sebagai pemimpin opini (orang yang dimintai pendapat tentang kesehatan dan pengaruh disabilitas untuk berperilaku sesuai dengan rekomendasi dalam pengobatan dan pencegahan penyakit dan orang tuna rungu (tuli) sebagai isolat (orang yang memiliki keterbatasan atau minim untuk mengakses informasi layanan kesehatan sebagai akibat dari keterbatasan dan metode penyampaian informasi menggunakan pengeras suara.
\end{abstract}

\author{
Kata Kunci: \\ Pola Jaringan Komunikasi, \\ Disabilitas, Bencana, Erupsi, \\ Layanan Kesehatan.
}




\section{PENDAHULUAN}

Bencana adalah peristiwa atau rangkaian peristiwa yang mengancam dan mengganggu kehidupan dan penghidupan masyarakat yang disebabkan, baik oleh faktor alam dan atau faktor non alam maupun faktor manusia sehingga mengakibatkan timbulnya korban jiwa manusia, kerusakan lingkungan, kerugian harta benda, dan dampak psikologi (UU No 24 tahun 2007 tentang penanggulangan bencana). Indonesia memiliki wilayah atau daerah yang rawan terhadap bencana khususnya bencana alam erupsi Gunungapi berapi sebab Indonesia terletak pada kawasan Pacific Ring of Fire.

Total 127 Gunungapi aktif berada di Indonesia dengan luas daerah rawan bencana Gunungapi sekitar $17.000 \mathrm{~km}^{2}$ dengan jumlah penduduk yang bermukim di kawasan rawan bencana Gunungapi sebanyak kurang lebih 5,5 juta jiwa ( PERKA BNPB Nomor 4 Tahun 2008). Gunungapi Merapi merupakan salah satu Gunungapi aktif di dunia dengan periode letusan yang pendek (antara 2-7tahun sekali) dan letusan terbesar terakhir terjadi pada Tahun 2010. Letusan tersebut menyebabkan ditetapkannya kawasan rawan bencana I,II dan III dan jarak aman untuk pengungsian mencapai radius $25 \mathrm{~km}$ dari gunungapi Merapi yang berlokasi di Gelanggang Olah Raga Universitas Negeri Yogyakarta dan Stadion Maguwoharjo.

Terdapat 3 tahap dalam penyelenggaraan penanggulangan bencana menurut pasal 33 Undang-Undang no 24 Tahun 2007 yaitu pra bencana, saat tanggap darurat dan pasca bencana. Pelayanan kesehatan merupakan penyelenggaraan penanggulangan bencana yang menjadi kebutuhan dasar pada saat tanggap darurat dan pasca bencana. Pelayanan kesehatan merupakan penyelenggaraan penanggulangan bencana yang menjadi kebutuhan dasar pada saat tanggap darurat dan pasca bencana. Layanan kesehatan harus terpenuhi sebab masyarakat yang terkena bencana rawan terserang berbagai penyakit. Dengan adanya layanan kesehatan yang baik maka diharapkan menjadi upaya pencegahan (preventif) agar masyarakat tetap dalam keadaan sehat selama menghadapi bencana. Penyandang disabilitas menjadi salah satu dari kelompok rentan yang berhak mendapatkan layanan kesehatan selama masa tanggap darurat maupun pasca bencana.

Menurut Fathoni dan Widayatun (2013: 37), bencana tidak hanya menimbulkan korban meninggal dan luka serta rusaknya berbagai fasilitas kesehatan, tetapi juga berdampak pada permasalahan kesehatan masyarakat seperti munculnya berbagai penyakit pasca gempa, fasilitas air bersih dan sanitasi lingkungan yang kurang baik, trauma kejiwaan serta akses terhadap pelayanan kesehatan reproduksi perempuan dan pasangan.

Dalam penyelenggaraan penanggulangan bencana baik pra, masa tanggap darurat maupun pasca bencana proses komunikasi menjadi hal penting sehingga setiap aktivitas dapat terkoordinir dan terlaksana dengan baik. Demikian pula halnya dalam memberikan layanan kesehatan kepada masyarakat terkena bencana khususnya penyandang disabilitas. Proses komunikasi terjadi antar sesama penyandang disabilitas, penyandang disbilitas dengan masyarakat maupun penyandang disabilitas dengan stakeholders yang berperan dalam memberikan layanan kesehatan.

Proses komunikasi dalam layanan kesehatan tersebut membentuk pola jaringan tertentu. Pola jaringan komunikasi menggambarkan terjadinya proses pertukaran informasi dengan individu lain yang membentuk suatu hubungan terpola dalam suatu rangkaian jaringan yang interaktif dengan peranan-peranan tertentu seperti opinion leader, gate keepers, cosmopolite, bridge,liaison dan isolate. Menurut Bulkis (2015 : 31) menyampaikan bahwa jaringan komunikasi merupakan gambaran dari who say to whom (siapa berbicara kepada siapa).

Dengan mengetahui pola jaringan komunikasi dapat memberikan gambaran bagaiman tahapan suatu informasi dapat tersebar dan siapa saja yang berperan penting dalam penyebaran informasi. Menurut Wardyaningrum (2016 : 36) kajian jaringan komunikasi memiliki kontribusi penting dalam mengkaji persoalan sosial bencana alam. Dengan kajian jaringan komunikasi sebagai aplikasi dari jaringan sosial yang diperdalam dengan kajian modal sosial dapat memberikan gambaran yang semakin lengkap guna memberikan alternatif bagi penanganan bencana secaralebih komprehensif.

Berdasar uraian tersebut maka peneliti menyimpulkan perlu adanya kajian atau penelitian tentang pola jaringan komunikasi khusus bagi penyandang disabilitas korban erupsi Gunungapi Merapi sehingga ke depan dapat menjadi bahan kajian lebih mendalam mengenai komunikasi kebencanaan yang efektif khususnya bagi penyandang disabilitas. Adapun tujuan jangka pendek penelitian ini yaitu untuk mengetahui pola jaringan komunikasi layanan kesehatan bagi penyandang disabilitas dan tujuan jangka panjang penelitian ini yaitu adanya rumusan komunikasi bencana bagi penyandang disabilitas mulai dari mitigasi dan kesiapsiagaan, masa tanggap darurat, serta masa recovery.

\section{KAJIAN LITERATUR}

\section{A. Komunikasi Bencana}

Komunikasi bencana merupakan sebuah proses penyampaian informasi tentang kesiapsiagaan, ketanggapdaruratan dan rehabilitasi rekonstruksi. Komunikasi dalam kesiapsiagaan bertujuan untuk meningkatkan kesiapan masyarakat menghadapi bencana yang dapat terjadi sewaktu-waktu (mitigasi). Komunikasi tanggap darurat penting dilakukan dengan memberikan informasi yang pasti,tidak simpangsiur kepada masyarakat baik mengenai jenis dan lokasi bencana, kekuatan,dampak, evakuasi, layanan kesehatan, dan sebagainya. Sedangkan pada tahap rehabilitasi dan rekonstruksi proses komunikasi bertujuan untuk mengembalikan kenyamanan, ketenangan, kepercayaan diri para korban dengan lingkungan sosialnya yang berubah pasca terjadi bencana. 
Menurut Davis dan Kapur (2014: 1) menyampaikan bahwa perlu membangun komunikasi sebelum bencana terjadi mencakup data dan informasi daerah yang potensial terkena bencana, jenis bencana,orang lokal dan lembaga atau organisasi yang menjadi contact person maupun sumber informasi yang dapat menyebarkan informasi dengan cepat. Komunikasi pada saat terjadi bencana (tanggap bencana) harus dapat dilakukan secara efektif agar dapat mengurangi resiko kematian, kerugian harta, kepanikan, ketidakpastian informasi pada masyarakat terutama yang menjadi korban bencana. Sedangkan komunikasi pasca bencana (rehabilitasi reknstruksi) berupaya untuk mekoordinasikan tindakan yang perlu segera dilakukan seperti penyaluran bantuan, penyediaan tenaga medis maupun psikolog, pembangunan hunian sementara huntara, relokasi, dan sebagainya

Kegiatan komunikasi bencana tersebut dapat terjadi secara langsung (direct) maupun tidak langsung (indirect). Berdasar penelitian Rahmawati, 2014: 36 bahwa pertemuan (direct communication) Pertemuan cukup optimal dalam persuasi atau membujuk masyarakat yang potensial terdampak bencana banjir lahar dingin di Kota Yogyakarta untuk meningkatkan kesiapsiagaan, sedangkan pada saat terjadi bencana (tanggap darurat) dan pasca bencana (rehabilitasi dan rekonstruksi) penggunaan media (indirect communication) sangat diperlukan untuk mempercepat dan memperluas jangkauan penyampaian informasi.

Komunikasi bencana yang berjalan dengan baik dapat meminimalkan terjadinya dampak primer maupun dampak sekunder. Oleh karenanya kejelasan informasi dari semua pihak sangat penting agar masyarakat memiliki pengetahuan dan ketrampilan dalam menghadapi bencana khususnya bencana erupsi Gunungapi Merapi.Sebagaimana disampaikan oleh Ayub,Hadi et.al (2014 :503) Communication is the best opportunity to clarify meaning and resolve uncertainty and misunderstanding. The way group members communicate with each other is crucial in determiningwhat happens when people collaborate.

\section{B. Dampak Bencana terhadap Kesehatan}

Kejadian bencana erupsi Gunungapi Merapi tahun 2010 telah menimbulkan dampak primer maupun dampak sekunder. Kondisi kesehatan masyarakat menjadi salah satu dampak primer akibat erupsi. Pada masa tanggap darurat hingga masa recovery (rehabilitasi) kesehatan masyarakat korban bencana harus mendapatkan perhatian sebab pada kondisi tersebut para korban rawan terserang berbagai macam penyakit. Disamping itu, sarana prasarana penunjang kesehatan juga perlu tersedia dengan memadai seperti jamban umum, air bersih, obat-obatan, tim medis, pembalut (bagi perempuan), susu dan makanan bayi.

Menurut forum PRB DIY (2010) dalam Fathoni dan Widayatun (2013:42) terdapat 10 (sepuluh) jenis penyakit yang paling banyak muncul pasca erupsi Gunungapi Merapi yaitu Infeksi Saluran Pernafasan (ISPA),cepalgia,myalgia, flu dan sejenisnya, hipertensi primer, penyakit atau iritasi mata,dispepsi, dermatitis kontak alergi,faringitis akut dan gastritis. Beberapa jenis penyakit tersebut juga menyerang korban bencan erupsi Gunungapi Sinabung yang terjadi dalam beberapa tahun belakangan ini. Para korban erupsi Gunung Sinabung umumnya banyak yang terserang berbagai penyakit seperti menurut Dinas Kesehatan Kabupaten Karo flu, sakit perut, dan batuk. Sedangkan untuk pengungsi anak-anak usia kurang dari lima tahun banyak terserang penyakit infeksi saluran pernafasan (ISPA) dan konjungtivitas. Beberapa pengungsi juga terserang hipertensi.

Berdasarkan informasi tersebut maka dapat disimpulkan bahwa bencana erupsi Gunungapi mempunyai dampak kesehatan cukup besar bagi masyarakat yang berada di sekitar lokasi bencana dari usia anak-anak hingga usia lanjut. Sehingga layanan kesehatan menjadi hal yang harus diprioritaskan baik preventif maupun kuratif yang dapat dilakukan dengan menyediakan jamban umum yang memadai, sanitasi air yang baik, tenaga medis dan kesehatan, obat-obatan dan kebutuhan khusus perempuan (pembalut), pemantauan kondisi kesehatan dengan pemeriksaan berkala secara rutin dan sebagainya.

Masalah paling sering terjadi ketika masa tanggap darurat dan rehabilitasi yaitu keterbatasan fasilitan jamban umum dan sanitasi yang buruk sehingga para korban mengalami keterbatasan untuk mendapatkan air bersih. Sanitasi yang buruk dan keterbatasan ketersediaan air bersih dapat menyebabkan timbulnya penyakit seperti gatal-gatal dan sakit perut. Oleh karena itu keterlibatan berbagai pihak sangat penting dalam pelayanan kesehatan seperti dokter, bidan, perawat, apoteker baik dari pemerintah maupun non pemerintah. Keterlibatan berbagai pihak tersebut dengan membuat posko kesehatan di lokasi pengungsian (dekat dengan lokasi bencana) agar tindakan gawat darurat dan pemantauan kesehatan pada korban dapat dengan cepat dan rutin dilaksanakan.

Dalam penanganan kesehatan terhadap korban bencana komunikasi interprofesional harus berjalan dengan efektif agar tidak terjadi medical error yang dapat membahayakan keselamtan atau bahkan nyawa pasien. Hal ini sejalan dengan yang dinyatakan oleh Nur dan Santoso(2018 : 29-33), bahwa komunikasi interprofesional dapat meningkatkan keselamatan pasien dan menurunkan angka insiden pasien. Komunikasi interprofesional berjalan tidak efektif salah satu penyebabnya karena koordinasi yang kurang baik antar tenaga kesehatan selama memberikan layanan kesehatan.

Selain komunikasi interprofesional, penting juga untuk mengembangkan komunikasi organisasi dengan berbagai pemangku kepentingan agar terjadi koordinasi yang baik sehingga semua korban dapat terlayani untuk pemantauan kondisi kesehatannya. 


\section{Pola Jaringan Komunikasi Layanan Kesehatan Disabilitas}

National Council on Disability Report (2014:10) menjelaskan Effective communication must be provided to all people with disabilities (komunikasi yang efektif harus diberikan kepada semua penyandang disabilitas). Penyandang disabilitas antara lain tuna rungu, tuna wicara, tuna netra, tuna daksa, tuna grahita, dan sebagainya. Dalam setiap kelompok penyandang disabilitas memiliki keterbatasan yang berbeda-beda sehingga dalam melakukan komunikasi semestinya berbeda juga menyesuaikan dengan keterbatasan yang dimiliki. Bagi penyandang disabilitas yang mempunyai keterbatasan dalam indera pendengaran maka komunikasi lebih banyak menggunakan komunikasi non verbal (gerakangerakan anggota tubuh). Sedangkan bagi penyandang disabilitas yang memiliki keterbatasan dalam indera penglihatan maupun keterbatasan gerakan tubuh maka penggunaan komunikasi verbal lebih sesuai. Ketika terjadi komunikasi antar individu atau grup maka aliran komunikasi terbentuk.

Aliran komunikasi tersebut membetuk pola-pola tertentu yang disebut dengan pola jaringan komunikasi. Pola jaringan komunikasi yaitu komunikasi membentuk pola dan aliran yang menghubungkan pengirim dan penerima pesan baik secara formal ataupun informal (Lunenburg, 2011 : 1). Jaringan komunikasi adalah pola hubungan yang terbentuk dari aliran pesan antar komunikator pada waktu dan tempat tertentu berupa informasi data, informasi pengetahuan, gambar-gambar, simbol dan berbagai bentuk simbol lain yang dapat terjadi antar anggota jaringan (Monge, 2003:1).

Pola jaringan komunikasi adalah struktur aliran komunikasi dalam sebuah organisasi, menggambarkan hubungan komunikasi dalam tim kerja berdasar struktur organisasi. Pola komunikasi bukan hanya sekedar sebuah instrumen tetapi juga menunjukkan budaya dalam sebuah organisasi. Pola komunikasi dalam organisasi menggambarkan komunikasi antar berbagai pihak yang ada dalam organisasi tersebut. Pola jaringan komunikasi berhubungan dengan efisiensi kerja dan siapa bertanggung jawab kepada siapa atau siapa berbicara dengan siapa, siapa bertanggungjawab apa. Komunikasi organisasi dapat dilakukan dengan upward, downward,horizontal dan diagonal. Pola jaringan komunikasi terdiri dari pola rantai (chain), pola roda (wheel), pola Y, pola lingkaran (circle) dan pola semua saluran (all channel).

Pola roda (wheel) yaitu pola jaringan komunikasi yang terstruktur dan tersentral karena masing-masing anggota dapat berkomunikasi hanya dengan satu orang atau sumber pesan terpusat pada satu orang. Pola rantai (chain) yaitu pola jaringan komunikasi yang terjadi dimana dua orang berkomunikasi satu sama lain, dan pada gilirannya hanya ada satu orang yang dikenal. Pola ini menggambarkan sebuah pola yang sangat terpusat atau tersentral. Pola Y yaitu hampir sama dengan pola rantai,yang membedakan dalam pola $\mathrm{Y}$ terdapat dua anggota yang berada di luar.

Pola lingkaran (circle) yaitu pola jaringan komunikasi yang menggambarkan setiap anggota memiliki kesempatan komunikasi setara dengan orang-orang di sekitarnya (kanan-kiri), dan memiliki batasan-batasan yang sama. Dalam pola jaringan lingkaran, setiap orang menjadi pengambil keputusan.Pola semua saluran (all channel) yaitu pola jaringan komunikasi yang menghubungkan semua orang di jaringan lingkaran sehingga membentuk bintang dan memungkinkan setiap anggota berkomunikasi bebas dengan semua orang lain atau disentralisasi (Lunenburg, 2011 :2).

Pihak-pihak yang terlibat dalam jaringan komunikasi memiliki peran masing-masing yaitu sebagai opinion leaders, gatekeepers, liaison, bridge,cosmopolite, dan isolate. Opinion leader adalah pimpinan informal organisasi yang melakukan fungsi kunci komunikasi dengan mempengaruhi pembentukan dan perubahan sikap. Opinion leader dimintai pendapat sedangkan anggota sebagai pendengar. Gate keepers yaitu individu yang mengatur atau mengontrol arus informasi diantara anggota organisasi, berada di tengah jaringan dan mempunyai kekuasaan untuk memutuskan perlu tidaknya pesan disampaikan kepada kelompok.

Cosmopolite yaitu individu yang menghubungkan organisasi dan lingkungannya, memiliki kontak dengan sumber di luar organisasi dan bertindak sebagai saluran bagi gagasan baru yang akan memasuki organisasi. Bridge yaitu anggota kelompok atau klik dari suatu organisasi yang menghubungkan kelompok itu dengan anggota kelompok lainnya. Liaison yaitu individu yang berperan sama seperti bridge akan tetapi individu tersebut bukan anggota dari satu kelompok.individu ini merupakan penghubungkan antara kelompok satu dengan kelompok lain, yang dapat mempercepat dan memperlambat informasi. Isolate yaitu anggota organisasi yang memiliki kontak minimal dengan orang lain dalam organisasi.

\section{METODE PENELITIAN}

Penelitian ini menggunakan metode kualitatif yaitu metode yang mengeksplorasi masalah sosial atau manusia secara induktif,dimana peneliti menggambarkan secara kompleks dan holistik, menganalisis kata-kata, menginterpretasikan informasi atau data yang diperoleh dari lapangan.

Lokasi penelitian di Wilayah Kabupaten Sleman. Informan penelitian yaitu pemerintah Kabupaten Sleman (Dinas Kesehatan, BPBD), Pemerintah Desa dan penyandang disabilitas yang berada di wilayah Kawasan Rawan Bencana II,III dan relawan yang memberikan layanan kesehatan pasca erupsi Gunungapi Merapi.Penentuan informan dilakukan secara purposive yaitu penentuan informan dengan pertimbangan tertentu (Sugiyono, 2018:138).

Jenis data dalam penelitian ini ada dua yaitu data primer dan data sekunder. Data primer adalah data yang diperoleh langsung oleh peneliti baik melalui wawancara, FGD (forum group discussion) maupun observasi. Data sekunder adalah data yang diperoleh dari arsip-arsip atau dokumen- dokumen yang telah ada, diperoleh dengan pendokumentasian 
maupun pencatatan.

Sedangkan teknik pengumpulan data melalui wawancara mendalam (depth interview), observasi, FGD (forum group discussion), pencatatan dan dokumentasi. Analisis data dalam penelitian ini menggunakan network commucication analysis yaitu analisis hubungan struktur sosial antar personal, grup atau organisasi dan masyarakat yang mempengaruhi perilaku atau kepercayaan.

Uji validitas dalam penelitian ini dengan menggunakan triangulasi yaitu melakukan pengecekan dari sumbersumber data yang berbeda dengan memeriksa bukti-bukti yang berasal dari sumber-sumber tersebut dan menggunakannya untuk membangun justifikasi tema-tema secara koheren (Creswell, 2010:285). Jenis triangulasi yang digunakan adalah triangulasi sumber yaitu membandingkan atau mengecek ulang derajat kepercayaan suatu informasi yang diperoleh dari sumber yang berbeda. Triangulasi dalam penelitian ini dilakukan dari sudut pandang peneliti, pemerintah, kepala desa, masyarakat penyandang disabilitas dan relawan.

\section{HASIL DAN PEMBAHASAN}

\section{A. Profil Penyandang Disabilitas}

Profil penyandang disabilitas memberikan gambaran mengenai umur, jenis pekerjaan,pendapatan, dan jumlah tanggungan keluarga. Penyandang disabilitas Berdasar hasil penelitian rata-rata umur penyandang disabilitas 37 tahun, yang berdasar kategori masuk dalam usia produktif. Jenis pekerjaan 75\% adalah swasta seperti berdagang, penambang pasir,penjahit, dan sebagainya sedangkan yang 25\% bekerja kantoran (karyawan) dengan rata-rata penghasilan per bulan Rp 1.420.000 ( Satu Juta Empat Ratus Dua Puluh Ribu Rupiah). Sedangkan rata-rata jumlah tanggungan keluarga adalah 3 orang yaitu 2 anak dan 1 istri. Dengan melihat profil tersebut menunjukkan bahwa penyandang disabilitas memiliki kemampuan untuk memperjuangkan kehidupan perekonomian diri dan keluarganya diantara berbagai kekurangan atau kelemahan yang dimiliki.

Disamping memperjuangkan kehidupan perekonomian, penyandang disabilitas ternyata juga mampu memperjuangkan keselamatan diri, anggota keluarga dan teman sesama penyandang disabilitas pada masa erupsi besar Gunungapi Merapi pada tahun 2010. Hal ini sebagaimana wawancara dengan Bapak Joko Budi Prayitno penyandang disabilitas yang tinggal di Kecamatan Turi

"Untuk keluarga saya waktu erupsi Merapi, pemerintah desa tidak mengkoordinir, untuk difabel mencari perlindungan sediri, dari Dukuh, RT/RW tidak ada bantuan khusus untuk difabel. Setelah sudah reda, saya mendirikan posko, dekat polda DIY, saya yang mengkoordinir Kecamatan Turi, dekat BPD jalan Magelang, kami dirikan posko, saya menjemputkan teman-teman difabel Turi."

Pernyataan bapak Joko tersebut menunjukkan kegigihan dan kepedulian seorang penyandang disabilitas untuk menyelamatkan diri, anggota keluarga dan sesama penyandang disabilitas dari bahaya erupsi Gunungapi Merapi. Minimnya perhatian maupun fasilitas khusus bagi penyandang disabilitas dari pemerintah mendorong semangat untuk dapat berbuat banyak bagi sesama penyandang disabilitas. Hal senada juga disampaikan oleh penyandang disabilitas Bapak Suryanto :

"saya mengungsi mandiri, saya tahu jika Merapi meletus itu karena melihat sendiri, tidak ada Informasi apaapa."

Fakta ini dapat menjadi landasan bahwa penyandang disabilitas harus mendapatkan bekal pengetahuan dan ketrampilan yang cukup untuk menghadapi bencana erupsi Gunungapi Merapi yang dapat terjadi sewaktu-waktu. Hal ini penting dilakukan agar dapat meningkatkan kesiapsiagaan dan mengurangi resiko jatuhnya korban saat bencana terjadi. Stigma negative bahwa penyandang disabilitas tidak dapat menolong harus dapat dihilangkan sebab faktanya bahwa dalam berbagai keterbatasannya, penyandang disabilitas mampu menolong dirinya sendiri dan orang lain yang ada di sekitarnya pada saat kondisi bencana.

\section{B. Layanan Kesehatan Penyandang Disabilitas}

Pengungsi korban erupsi gunungapi Merapi tahun 2010 mendapatkan layanan kesehatan dari berbagai elemen baik pemerintah maupun non pemerintah. Layanan kesehatan tersebut tersedia untuk seluruh pengungsi tanpa ada pembedaan atau spesifikasi bagi penyandang disabilitas. Hal ini sebagaimana disampaikan Dinas Kesehatan Kabupaten Sleman, PMI Kota Yogyakarta dan penyandang disabilitas sebagai berikut :

"Kami tidak membedakan pelayanan kesehatan antara difabel dan masyarakat umum. Kalau dulu memang tidak menyediakan karena data juga tidak dapat dipastikan, dari dinas sosial, PPDI dan lainnya belum ada data valid terkait penyandang disabilitas"(Dinas Kesehatan Kabupaten Sleman, 13 Agustus 2018)

"PMI sudah standby terkait merapi tetapi kita belum memberikan pelayanan khusus terhadap difabel karena waktu itu belum ada aturan khusus. Tidak ada layanan khusus informasi difabel tetapi setiap anggota PMI sudah dibekali cara pelayanan khusus" (PMI Kota Yogyakarta, 13 Agustus 2018) 
"Penanganan kesehatan untuk teman-teman penyandang disabilitas enggak dibedakan dengan masyarakat umum, masih sama (Ibu Diah, Penyandang Disabilitas Kecamatan Turi)

Berdasar Informasi tersebut, hal yang menyebabkan belum tersedianya layanan kesehatan khusus bagi penyandang disabilitas yaitu ketersediaan data pengungsi penyandang disabilitas yang valid dan belum ada aturan khusus yang mengatur tentang penanganan disbilitas korban bencana. Hal tersebut kurang sejalan dengan aturan dalam UndangUndang Penanggulangan Bencana No 24 tahun 2007. Pasal 54 dan Pasal 55. Pasal 54 menyebutkan bahwa penanganan masyarakat dan pengungsi yang terkena bencana dilakukan dengan kegiatan meliputi pendataan, penempatan pada lokasi yang aman, dan pemenuhan kebutuhan dasar. Sedangkan pasal 55 ayat 2 yang secara eksplisit menyebutkan bahwa penyandang disabilitas merupakan salah satu kelompok rentan dalam penanganan bencana. Kelompok rentan mendapatkan prioritas perlindungan dengan penyelamatan, evakuasi, pengamanan, pelayanan kesehatan, dan psikososial. Fakta ini hendaknya menjadi evaluasi bagi setiap stakeholders yang terlibat dalam penanggulangan bencana erupsi gunungapi Merapi agar penyandang disabilitas mendapatkan prioritas khususnya layanan kesehatan selama masa tanggap darurat, rehabilitasi dan rekonstruksi serta recovery.

\section{Jaringan Komunikasi Layanan Kesehatan}

Proses komunikasi dalam penanganan bencana menjadi salah satu bagian yang penting untuk diperhatikan sebab ketidakjelasan atau kesimpangsiuran informasi dapat meminimalkan terjadinya kebingungan masyarakat terutama pada saat evakuasi dan saat di pengungsian. Kondisi masyarakat korban erupsi Gunungapi Merapi rentan terhadap serangan berbagai penyakit, demikian halnya dengan penyandang disabilitas. Oleh karena itu layanan kesehatan di lokasi pengungsian menjadi hal harus tersedia sehingga setiap saat masyarakat dapat melakukan pemeriksaan atas kondisi kesehatannya selama berada di pengungsian.

Untuk memberikan layanan kesehatan yang baik dan memadai maka hendaknya terdapat informasi yang jelas kepada penyandang disabilitas mengenai ketersediaan layanan kesehatan, cara melakukan pemeriksaan di layanan kesehatan yang tersedia, jenis penyakit yang di derita penyandang disabilitas, waktu atau jam layanan, upaya promotif, preventif dan kuratif selama berada di pengungsian dan sebagainya.Kejelasan Informasi tersebut dapat meminimalkan kebingungan penyandang disabilitas untuk mengakses layanan kesehatan sehingga setiap saat memerlukan pemeriksaan terhadap kondisi kesehatannya dapat memanfaatkan dengan baik. Penyakit yang paling banyak di derita korban erupsi gunungapi Merapi adalah sesak nafas sebagaimana disampaikan oleh Kepala Desa Girikerto berikut :

"Ya Alhamdulillah, masyarakat tidak ada yang sakit parah, ya umumnya sakit sesak nafas karena terkena $a b u$ ”

Berdasar hasil penelitian bahwa penyandang disabilitas memperoleh informasi mengenai layanan kesehatan dari relawan-relawan yang bertugas di pengungsian. Para relawan memberikan informasi melalui microfon sehingga didengar oleh semua pengungsi kecuali penyandang disabilitas yang tuli atau tuna rungu. Belum ada informasi khusus bagi penyandang disbilitas, sehingga bagi yang tuna rungu akan memperoleh informasi dari anggota keluarganya.

Kondisi alur informasi layanan kesehatan tersebut membentuk pola jaringan komunikasi layanan kesehatan disabilitas korban erupsi gunungapi Merapi. Pola roda (wheel) yaitu pola jaringan komunikasi yang terstruktur dan tersentral karena terdapat satu sumber pesan yaitu relawan yang menyampaikan pesan mengenai layanan kesehatan kepada pengungsi baik penyandang disabilitas dan masyarakat umum secara bersamaan melalui pengeras suara (microfon). Dengan pola jaringan komunikasi wheel maka dapat meminimalkan ketidakakuratan atau ketidakpastian informasi sebab terdapat simpul informasi yang jelas yaitu relawan.

Sedangkan dari sisi peran dalam jaringan, maka relawan sebagai Liaison, pihak pemberi layanan kesehatan sebagai opinion leader dan difabel tuli atau tuna rungu menjadi Isolate. Liaison yaitu individu yang bukan anggota dari satu kelompok dan berperan menghubungkan antara kelompok satu dengan kelompok lain dan keberadaannya dapat mempercepat dan memperlambat Informasi. Dalam hal ini relawan menghubungkan antara kelompok pengungsi khususnya penyandang disabilitas dengan kelompok penyedia layanan kesehatan. Apabila relawan tidak segera memberikan Informasi secara jelas mengenai layanan kesehatan kepada pengungsi maka hal tersebut dapat memperlambat tersampaikannya pesan sehingga menghambat pengungsi khususnya penyandang disabilitas untuk memperoleh layanan kesehatan. Sebaliknya jika relawan dengan segera menyampaikan Informasi secara jelas maka dapat mempercepat tersampaikannya pesan sehingga pengungsi khususnya penyandang disabilitas dapat segera mengakses layanan kesehatan yang tersedia

Tim medis sebagai opinion leader artinya tim medis yang memberikan layanan kesehatan menjadi kunci atau simpul sumber Informasi terkait kondisi kesehatan pengungsi khususnya penyandang disabilitas, tim medis dimintai pendapat oleh penyandang disabilitas tentang kondisi kesehatan kemudian tim medis memberikan anjuran hal-hal yang harus dilakukan dan dihindari penyandang disabilitas untuk memulihkan dan atau menjaga kondisi kesehatannya. Sedangkan penyandang disabilitas tuna rungu sebagai isolate artinya penyandang disabilitas yang mempunyai keterbatasan akses informasi akibat dari keterbatasan kemampuan pendengarannya karena penyampaian Informasi hanya menggunakan pengeras suara. Penyandang disabilitas kelompok ini akan mengetahui ketersediaan layanan kesehatan hanya jika diberiatahu oleh anggota keluarganya yang mempunyai kemampuan bahasa isyarat. 


\section{KESIMPULAN}

Kesimpulan berdasar hasil penelitian sebagai berikut :

1. Penyandang disabilitas mendapatkan Informasi mengenai ketersediaan layanan kesehatan, cara mengakses layanan kesehatan, waktu pelayanan dan sebagainya dari relawan-relawan di pengungsian

2. Pola jaringan komunikasi layanan kesehatan penyandang disabilitas korban erupsi gunungapi Merapi yaitu Wheel atau roda, relawan menjadi sumber atau simpul Informasi

3. Peran dalam jaringan komunikasi layanan kesehatan penyandang disabilitas korban erupsi gunungapi Merapi yaitu relawan sebagai liaison, tim medis sebagai opinion leader dan penyandang disabilitas tuna rungu (tuli) sebagai isolate.

\section{DAFTAR PUSTAKA}

Ayub, Hadi et al.Procedia Social and Behavioral Sciences 155 Oktober 2014: p 502 - 506 The International Conference on Communication and Media, Langkawi, MALAYSIA

Creswell, J.W., 2010, Research Design : Pendekatan Kualitatif, Kuantitatif danMixed, Pustaka Pelajar, Yogyakarta.

Fathoni dan Widayatun. Jurnal Kependudukan Indonesia Vol. 8 No.1 Tahun 2013 (ISSN 1907-2902) hal 37-52

Littlejohn 1992. Theories of Human Communication. Fourth Edition. Wadsworth Publishing Company Belmont California

Lunenburg C.Fred. 2011. National Forum of Educational Administration and Supervision Journal Volume 28, Number 4 (Network Patterns and Analysis: Underused Sources to Improve Communication Effectiveness), p 1-7

Medford-Davis, Laura N and Kapur G Bobby, 2014. Preparing for effective communications during disasters: lessons from a World Health Organization quality improvement project. International Journal of Emergency Medicine 2014, 7:15

Monge and Contactor.2003.Theories of CommunicationNetworks.Oxford University Press

National Council on Disability .2014. Effective Communications for People with Disabilities: Before, During, and After Emergencies. 1331 F Street, NW, Suite 850

Nur, Ainin Hirza dan Santoso,Agus 2018. Komunikasi Interpersonal dalam Peningkatan Keselamatan Pasien : Systemic Review. Jurnal Kepemimpinan dan Manajemen Keperawatan Volume 1 Nomor 1 Halaman 28-34

Rahmawati, Wuri. Jurnal Penanggulangan Bencana, Volume 5, Nomor 1, Tahun 2014 p 25-40

Sugiyono (2018). Statistika untuk Penelitian, CV Alfabeta, Bandung.

Wardyaningrum, Damayanti. Jurnal ASPIKOM, Volume 3 Nomor 1, Juli 2016, p 33-55 
